\title{
Development of SAMARC: South African format for the exchange of machine-readable bibliographic descriptions
}

\author{
H.S. Coetzee \\ Department of Information Science, University of Pretoria, Pretoria, 0002 Republic of South Africa \\ coetzee@libarts.up.ac.za
}

Received June 1997; accepted June 1997

\begin{abstract}
In the early sixties, the Library of Congress decided to computerize its cataloguing procedures to promote co-operation between libraries in America. For this purpose the MARC (Machine-readable cataloguing) format was developed. This had far-reaching implications worldwide and other national formats were developed as well as attempts made to achieve international standardization. In South Africa the National Library Advisory Council (NLAC) followed these developments with great interest and decided to instigate surveys and investigations to establish possible utilization of MARC records by South African libraries. The possibility of a computerized network was also investigated, for which an exchange format would also be a prerequisite. In 1982 the first edition of SAMARC: South African format for the exchange of machine-readable descriptions was published. Since then a number of important developments in various fields made it essential that the format be updated and revised. A draft second edition was made available in 1993 and the SAMARC manual was published in 1995 by the State Library. In April 1997 it was however decided by the South African library community to change to USMARC.
\end{abstract}

Aan die begin van die sestigerjare het die Library of Congress besluit om sy katalogiseringsprosedures te rekenariseer ten einde samewerking tussen biblioteke in Amerika te bevorder. Vir hierdie doel is die MARC (Machine-readable cataloguing) formaat ontwikkel. Dit het verreikende gevolge wêreldwyd gehad en ander nasionale formate het ook ontstaan. Pogings is ook aangewend om internasionale standaardisasie te bewerkstellig. In Suid-Afrika het die Nasionale Biblioteekadviesraad (NBAR) hierdie verwikkelinge met groot belangstelling dopgehou en besluit om opnames en ondersoeke te loods ten einde moontlike benutting van MARC-rekords deur Suid-Afrikaanse biblioteke te bepaal. Die moontlikheid van 'n rekenaarnetwerk is ook ondersoek. 'n Uitruilformaat sou hiervoor ook 'n voorvereiste wees. In 1982 het die eerste uitgawe van die SAMARC: South African format for the exchange of machine-readable descriptions verskyn. As gevolg van ingrypende ontwikkelinge op verskeie terreine het dit egter nodig geword om die formaat te hersien en op te dateer. ' $n$ Konsep tweede uitgawe het in 1993 verskyn en die SAMARC manual is in 1995 deur die Staatsbiblioteek uitgegee. In April 1997 is daar egter deur Suid-Afrikaanse biblioteke besluit om na USMARC oor te skakel.

At a recent seminar held in Pretoria, the majority of representatives from a wide range of institutions, system vendors and SABINET, decided not to continue using SAMARC as a national exchange format, but to change over to USMARC. Many reasons were given (Snyman 1997:47). The most important reason probably being that the Gauteng and Environment Library and Information Consortium (GAELIC) recently formed with the main purpose of promoting resource sharing among its members, and six of its member libraries could no longer postpone acquiring a new library system, and have chosen an American system based on USMARC. As most institutions in South Africa acquire mostly English language items for which bibliographic records are readily available in USMARC format, it is clearly not cost effective to convert all these records into SAMARC for local use. Another very important reason is that SAMARC has not been properly supported and maintained since its publication in 1982. At first the responsibility rested with the Council for Scientific and Industrial Research (CSIR), and with Ilse van Niekerk, compiler and editor of the first edition and all subsequent editions, being responsible in her personal capacity for everything connected with SAMARC and doing most of the development work after hours. The CSIR provided secretarial support and seconded Anne Schuster for a limited period to provide linguistic editorial support for the first edition. When Van Niekerk left to join SABINET in 1983, the network assumed technical responsibility for the format with Van Niekerk still doing the development work with limited secretarial support under the umbrella of the Network Standards Committee. Even the limited office time spent on SAMARC format was further curtailed in the period from 1988 to early 1991, when she left SABINET and all development work ceased for approximately three years. The South African National Library Advisory Council (NLAC), originally responsible for the development, publication and distribution of the format, had since ceased to exist, which meant that after the last copies had been sold by the Department of National Education, the format became out of print and therefore unavailable to the library community. Van Niekerk left SABINET and offered her services to the South African Institute of Library and Information Science (SAILIS) Committee on Bibliographic Control, then nominally responsible for SAMARC, to update the format. The Committee requested the State Library to assume future responsibility for publishing SAMARC and to provide training courses for cataloguers. An agreement was reached and the SAMARC manual was published in 1995. Quite a lot of work still needs to be done before the revision could be regarded as up-to-date, but all further development of the 
format will probably be suspended, although many libraries will for some time to come still make use of it.

The aim of this article is to give a brief overview of the origin of the MARC format in the United States and developments in other countries relating to MARC, international standardization of MARC formats, consequent research into its possible applications in South Africa, culminating in the development of a national format for South Africa, and eventually the publication of SAMARC in 1982 and the SAMARC manual in 1995. An attempt will also be made to give an explanation why adequate support for SAMARC was not provided after its initial success, leading to its replacement by USMARC by a number of libraries, and probably by the emerging regional consortia.

\section{Development of the MARC project in the United States}

In 1901 the Library of Congress began distributing printed catalogue cards, starting the widespread acceptance of the value of centralized and co-operative cataloguing (Chan 1985:325). In the early 1960s, the Library of Congress was obliged by congressional legislation, namely the Higher Education Act of 1965, to obtain and catalogue an increased number of publications from all over the world, thereby placing a huge burden on their skilled cataloguers. This Act set in motion the National Program for Acquisition and Cataloging (NPAC), also known as the Shared Cataloging Program. The aim of this program was to obtain and catalogue virtually all currently published foreign monographs commercially available and make the cataloguing data of these publications generally and speedily available to all libraries interested in acquiring these records (Piggott 1988:15).

In the late 1950s the Library of Congress started investigations into the possibility of using automated techniques for its internal operations. In the early 1960 s a feasibility study was done with financial support from the Council on Library Resources. A further study by the Library of Congress investigated possible methods of converting data on LC-printed cards to machine-readable form, making the production of bibliographic data by computer possible. Much interest and enthusiasm was created for this project and the Library of Congress obtained a grant from the Council on Library Resources to initiate a pilot project investigating possible implementation of methods recommended in these studies (Chan 1985:329).

The pilot project started in 1966 and was called MARC I, an acronym for Machine-Readable Cataloguing. The first few months were devoted to the development of procedures and computer programmes for the conversion, file maintenance and distribution of MARC data, as well as programmes to use the data at participating libraries (Chan 1985:329). It consisted of a weekly distribution service of machine-readable tapes containing bibliographic data, to 16 selected libraries of different types and in different geographical locations. These tapes were then processed through the computing facilities of these libraries. It was mainly used for the production of catalogue cards. Between November 1966 and June 1968, approximately 50000 cataloguing records for English language book materials were distributed (Chan 1985:329). MARC developed essentially as a processing format for Library of Congress (LC) and therefore carries many fields for internal LC data.

The results of the pilot project were sufficiently encouraging for the Library of Congress to proceed with further development on a full-scale basis. The limitations of MARC I were taken into account and it was followed by a more advanced and more flexible version in 1967, called MARC II. The MARC Distribution Service was also established in March 1969, to disseminate MARC records to participating libraries and institutions (Chan 1985:329). Initially about 50 libraries received tapes on a subscription basis.

MARC II consisted of fields of variable length as well as fixed length fields. Apart from the information which would be found in a full description according to AACR2, the format contained many additional fields, for example for classification numbers, subject headings and information of local significance. The format also catered for a variety of library materials. Initially the tapes included only records for English-language monographic materials, but coverage was gradually increased to include other library materials, such as archival material, audiovisual material, computer files, films, manuscripts, maps, music and serials. In 1973 the 'English language's only' record content was expanded to include nonEnglish materials (Library technical services 1984:53). Input is currently done in more than 130 roman alphabet languages, as well as a number of non-roman alphabet languages (Chan 1985:329; Wynar 1992:500).

The decision of the Library of Congress to transfer its current cataloguing data to machine-readable tapes, started a revolution in cataloguing worldwide (Piggott 1988:15). It provided a common format or framework which made it possible to exchange bibliographic descriptions in a machinereadable form between various computerized library systems, regionally, nationally and internationally, even though the descriptive content of these records varied (Roos 1994:26). MARC filled the need, at first in the United States and the United Kingdom, but later across the world, for a standardized format for libraries wishing to co-operate in the creation of bibliographic records, eliminating the necessity of duplication of cataloguing effort. Many other countries developed their own national exchange formats based on LCMARC but incorporating additional national requirements. It also met the requirements for the compilation of national bibliographies. Since the mid-1960s, because of its increased use and success, the MARC formats also provided a surge of enthusiasm for the automated support for library operations in many institutions (Library technical services 1984:52). Most networks worldwide, making use of both centralized and shared cataloguing procedures, are MARC-based.

A format however only provides a framework and structure for bibliographic data. The MARC format consists of a record 
label, a directory, indicators, tags and subfield codes. The fixed or control fields contain coded information and the fields of variable length contain the actual bibliographic data, which include a full bibliographic description and headings according to AACR2, subject data and other supplementary information.

Consistent record formats and content designation make both exchange and analysis of bibliographic data feasible in ways not previously in the realm of possibility. MARC has spread its influence across the whole spectrum of library activities, such as selection, ordering, cataloguing, information retrieval and the compilation of bibliographies (Hunter \& Bakewell 1991:136-137). The format contains many more fields than needed by the average library, but has many potential uses if required, facilitating reformatting for a wide variety of purposes (Rowley 1992:72).

At present there are a number of USMARC formats: USMARC format for bibliographic data, designed to hold bibliographic records for books, serials, archival and manuscript materials, computer files, maps, music and visual materials, as well as USMARC format for authority data, USMARC format for holdings data, USMARC format for community information and USMARC format for classification data. USMARC is continuously revised (Attig 1989: 136).

In 1969 the Council on Library Resources made a grant to Library of Congress to fund a feasibility study on the possibility of doing retrospective conversion. The Library of Congress then undertook the Retrospective Conversion Program (RECON), using the MARC format. The Cooperative Machine Readable Program (COMARC) was also initiated to explore the possibility of having co-operating libraries supply records for monographs to Library of Congress for verification against its official catalogue and for distribution through the MARC Distribution Service (Library technical services 1984:54) The tremendous increase in the number of items published, dwindling budgets, and increased demands of users, made it virtually impossible for libraries to keep providing adequate services. The development of computer and telecommunication technology made it possible however, to share a variety of resources, including bibliographic records. The MARC format provided the vehicle for sharing bibliographic data (Wynar 1992:499).

\section{Development of the UKMARC format in the United Kingdom}

The staff of the British National Bibliography initiated the British MARC project in 1967. By 1973 tapes of its weekly output was supplied selectively to a number of libraries, some of which was using it experimentally. It became fully operational in 1975. It has many similarities with USMARC, but the differences are significant and make conversion between the two formats complex. It is used by the majority of libraries in the United Kingdom even though some use USMARC. UKMARC was also used as the basis for some formats, such as those in Sweden and Denmark.

\section{International standardization of MARC formats}

ISO 2709: Documentation - format for bibliographic interchange on magnetic tape

Because the USMARC formats proved to be an effective means by which interlibrary co-operation can be achieved, co-operation increasingly depends on it and Hagler (1991: 245) declares emphatically that it will never be replaced by anything significantly different. Only time will tell if this is true, because technology might make another format for the exchange of data possible in the future. Because of the enormous cost of developing processing formats, USMARC also became a model to be followed in other countries. Minor variations to cater for local needs were however common and it became necessary to provide a more abstract guide to keep it from fragmenting into incompatible parts. It was also highly desirable for an international standard machinereadable format to be developed which took abstracting and indexing services into account, making it possible to cooperate in this respect. In 1973 the International Standards Organization (ISO) published its standard ISO 2709: Documentation format for bibliographic interchange on magnetic tape. Various international exchange formats are also based on ISO 2709, such as the UNISIST reference manual, UNI$M A R C$ and the Common Communication Format. The publication of this standard was a milestone in the international exchange of bibliographic data, making formats developed after its appearance in 1972 more compatible. ISO 2709 only governs the structure of formats and is not limited to bibliographic records. It does not prescribe the content within the format structure. The record content is usually controlled by national cataloguing agencies and practised in their national bibliographies.

\section{UNIMARC: Universal MARC format}

As the use of MARC became more widespread, the format was developed and adapted by its various user organizations and institutions according to their disparate requirements (Review of metadata 1997:1). A number of national MARC formats emerged since Library of Congress took the lead in 1966, closely followed by UKMARC in 1969. Each of these formats follow ISO 2709, but because of certain continuing differences in cataloguing practice, there are national variations in tag assignments and data definition. Conversion programmes therefore had to be written if a national agency wanted to process information from another national agency, a process with considerable cost implications. About 30 MARC formats were eventually developed, some based on USMARC and UKMARC. The International Federation of Library Associations (IFLA) then decided on the development of UNIMARC, intended as a communication format, conforming to ISO 2709, which would make it possible to write and maintain only two conversion programmes, one from the national format to UNIMARC and one from UNIMARC to the national format. UNIMARC standardizes 
content designators for a core element, and a descriptive block according to ISBD.

UNIMARC: universal MARC format was published in 1977, and a second edition, which added specifications for cartographic materials appeared in 1980. In the same year the national libraries of the United Kingdom, Australia, Canada and the United States committed themselves in principle to exchanging records in the UNIMARC format. A test involving nine national libraries was commissioned by the International MARC Network Study Steering Committee in 1981. The Deutsche Bibliothek analysed the results, which demonstrated that the use of the UNIMARC format would be facilitated by interpretation. To achieve this, the British Library and the Library of Congress collaborated to produce the UNIMARC handbook, which was published by IFLA in 1983 (Hunter \& Bakewell 1991:141; Roos 1994:27).

In 1986 a meeting of UNIMARC users was held under the auspices of the International MARC programme at the British Library. A number of proposals and amendments were discussed and specifications for several non-book materials were finalized. The result of this was the publication of the UNI$M A R C$ manual in 1987. An updated edition was published in 1994. Records in the UNIMARC exchange format were then offered by the national bibliographic agencies of a number of countries, including the Federal Republic of Germany, France, Hungary, Portugal, South Africa and Taiwan. The IFLA UBCIM (Universal Bibliographic Control International MARC) Programme continues to promote and maintain the UNIMARC format. It is supervised by the Permanent UNIMARC Committee (PUC), under the auspices of the UBCIM Programme.

UNIMARC came too late to be adopted as an international exchange format, because too many formats were already in existence at that time. It was however a true international effort, totally compatible, flexible, linkable and stable (Review of metadata 1997:1). UNIMARC could make a significant contribution to the Universal Bibliographic Control Programme, enabling national agencies who want to use cataloguing data produced by the national agency where a particular item originated, thus cutting costs (Hunter \& Bakewell 1991:142). It is widely used in Europe, Asia and parts of Latin America. It is translated into the language of the country and used as a national format in that country. It is difficult to ascertain to what extent it is presently used as an international exchange format. All national formats based on UNIMARC, such as SAMARC, can easily exchange bibliographic data, because the formats are compatible. South African libraries however mainly acquire materials from the United States and the United Kingdom and relatively few in languages other than English. The Library of Congress did have a few subscribers, requiring records in the UNIMARC format, but this service has been discontinued because of dwindling demand. Library of Congress and the British Library do not supply bibliographic data in UNIMARC format any more, expecting other countries using their
MARC records to convert directly from USMARC and UKMARC to their national formats.

The influence of the Library of Congress and therefore also of USMARC worldwide, with a format created before ISBD, ISO 2709 and AACR2, has hampered the optimal expansion of the use of UNIMARC in geographic areas outside Europe. UNIMARC is in many ways a more logical and a structurally better format than USMARC and also more concise, but cooperation between the United States and European nonEnglish speaking countries does not seem to be a priority for any of them and these two spheres of influence are both strong. Some European libraries have joined American networks, such as OCLC, expanding the influence of USMARC even further than before. South Africa, forming part of the Anglo-American information community, is therefore an anomaly, having a format based on UNIMARC.

A UNIMARC authorities format was also developed in the late eighties. When SAMARC was being revised, it was envisaged that a SAMARC authorities format, based on UNIMARC authorities would be developed without too much effort, as soon as funds could be obtained. The absence of a national authorities format was quoted as one of most important disadvantages of continued use of SAMARC by South African libraries (Snyman 1997:47).

\section{Future of the MARC formats}

There has always been a close relationship between descriptive cataloguing rules and MARC formats and their different characteristics influence each other. Attig (1989:135) declares:

'The relationship has become so close that periodically we hear suggestions that the cataloguing rules be rewritten in MARC tags or that a single standard should govern both the coding and the content of MARC records'.

He also states that cataloguers have been forced to acknowledge that while MARC has a special relationship with AACR2, it cannot be combined in a single set of rules. MARC must serve as a vehicle for bibliographic and authority data of all types from all agencies, including those who do not use AACR2 (Attig 1989:140). MARC is only a communications format and communicates bibliographic records. It is very difficult to communicate relationships between records, an important aspect of bibliographic control. The pace in the development of codes and formats has slowed in the late eighties and early nineties, but renewed interest is evident lately. Two international conferences on aspects of cataloguing are planned for the next year. It is essential that descriptive cataloguers and MARC format designers understand what the fundamental concepts of both are and that they work together to refine and develop those concepts in the light of new challenges (Attig 1989:147). At a forthcoming conference on the future of AACR, being held in Toronto in October 1997, much time will be devoted to this question. It is felt that AACR2 is not ideally suited for computerized environments and still contains many card-catalogue- 
orientated elements. It is also no longer essential to distinguish between main and added entries, but AACR2 is still based on this principle. The MARC formats also make provision for options of primary responsibility and also distinguishes between alternative and secondary responsibility, requiring added entries. Both codes and formats will therefore have to change in this as well as in other respects.

Michael Gorman, co-editor of AACR2, is very critical of the MARC formats, declaring that it 'has been a major influence for good or ill on descriptive cataloguing for more than twenty years'. He also maintains that MARC was initially developed to mechanize the production of $\mathrm{LC}$ catalogue cards and

'in this genesis lies the fatal flaw that hinders descriptive cataloguing to this day and will hinder it for years to come. The MARC format is not and never was a rethinking of the nature of bibliographic data. It embodies none of the ideas concerning the linkage of bibliographic descriptions and authority records' (Gorman 1990:72).

According to him all the other formats developed traditionally and book-oriented and UNIMARC

'represents the lowest common denominator of the various national formats. The irony is that we have a vehicle that has allowed an unprecedented level of international and national exchange of bibliographic data ... but that vehicle bears the same relationship to a true computerized bibliographic format as a Model $\mathrm{T}$ does to a Concorde. The very success of MARC has created an inert mass that becomes daily more resistant to change. In the future as in the past, descriptive cataloguing will be concerned with the recording of descriptive data and the provision of access to that data. However the structures within which description and access are accomplished may be very different. The MARC formats are the keys to change. If they remain more or less as they are, it is hard to see how the cataloguing rules for access points can change. If those rules do not change, it is hard to see how the standard description plus authority records concept can be assimilated fully into cataloguing theory and practice' (Gorman 1990: 71)

At the conference in Toronto in October 1997, decisions will have to be taken by national representatives of a large number of countries, to try and resolve these problems. Ways will have to be found to harmonize rules for bibliographic description with the formats used to exchange bibliographic data.

At present there is a move towards convergence and harmonization of MARC formats. The need for easy exchange is recognized by all users of MARC formats. A programme has been established to harmonize CANMARC, USMARC and UKMARC, although both the British Library and the Library of Congress have declared themselves committed to the development of UNIMARC. It is however not clear what this commitment entails, because neither of them use UNIMARC or supply records in this format. Englishspeaking countries are apparently converging towards USMARC and European and Asian countries towards UNIMARC. USMARC is continuously expanding its influence right across the world, with American networks acquiring members around the globe, providing bibliographic data in the USMARC format (Review of metadata 1997:1).

An agreement has been reached on the full harmonization of USMARC and CANMARC. UKMARC however has to retain certain features of particular use to UKMARC users. Full harmonization will therefore not be possible in the short term. Users of UKMARC have a big problem with the fact that USMARC demands cataloguer input of punctuation and not by more specific subfield coding. This causes lack of data definition for UKMARC conversion to USMARC and cannot be recreated with USMARC to UKMARC conversion. The advantages of harmonization are that it could cut cataloguing costs, reduce the number of standards that has to be applied and that a larger pool of bibliographic records would be available to potential users. This trend towards convergence of formats has also been given as another advantage for the use of USMARC instead of SAMARC by South African libraries (Snyman 1997:47). It is possible that SAMARC, like UKMARC, also has specific features, uniquely applicable in the South African environment and for which USMARC does not make provision. This is one of the reasons for the establishment of a permanent MARC office at the State Library, even though the GAELIC members do not regard it as essential. The problem of multilingualism is of no importance to the Library of Congress, but will increasingly, as publications in indigenous languages increase, be a problem for South African libraries.

\section{Development of a MARC format for South Africa}

Developments and investigations by the Library of Congress in the mid-sixties and their impact on library mechanization and co-operative cataloguing, was followed with great interest by the South African National Library Advisory Council, which was established in 1967, to assess its potential applications in a South African environment. Quite a number of South African libraries were computerizing their services or planning to do so. The NLAC was convinced that this should develop on a co-ordinated and standardized basis. A Subcommittee on Information Retrieval was established to look into developments abroad, do a survey on computerized systems already in existence in South Africa and determine whether libraries in South Africa already participated in international cataloguing services by using magnetic tape services such as MARC. At the Subcommittee's request the Council for Scientific and Industrial Research (CSIR) made a project officer available to carry out the investigation. 


\section{Preliminary investigation 1970}

Twenty five libraries were visited and questioned and it was found that in the field of computerization little co-operation existed and that there was a lack of standardization and suitably trained staff. There was consensus that efforts relating to MARC in South Africa should be handled by a central organization and that experimentation should start as soon as possible. Some doubts were however expressed about the usefulness of a MARC tape service to individual libraries. It was felt that the building up of a computerized joint catalogue using MARC tapes would be more useful (Kingwill 1979:5).

\section{Feasibility study 1972 to March 1977}

Because the NLAC was convinced that MARC was the most practical method of achieving co-ordination and standardization in mechanized library systems and that MARC tapes could be used to provide a national service, the Committee on Bibliographic Services was appointed in 1971. Their brief was to co-ordinate a feasibility study, carried out by the CSIR, the State Library and other libraries with computerized systems, into possible subscription to MARC tapes and similar internationally available services. The Committee also had to establish if the State Library could provide a national service by subscribing to MARC tapes, linking this project to the computerization of the South African National Bibliography and the Joint Catalogue. Emphasis in this investigation had to be placed on standardization to achieve coordinated development and libraries had to be made aware of the advantages of developing systems which were MARC compatible.

The CSIR drew up a proposal for the feasibility study which was discussed at a meeting attended by 12 institutions in Pretoria in March 1972. The proposal was approved and an ad hoc Working Group of five libraries in the Pretoria-Johannesburg area was requested to carry out the study. The study was aimed at establishing the advantages to libraries with computerized systems of using MARC tapes. It also had to determine if a MARC centre should be established in South Africa, which services should be provided by such a centre and what it would cost to provide such a service (Kingwill 1979:6).

The study was carried out in two phases, consisting of a survey of technical processing procedures in South African libraries, a detailed study of monograph acquisitions in six libraries, and a cost estimate of running an experimental MARC service.

Questionnaires were sent out to 40 libraries of which 35 were returned, showing that the majority of libraries were using the Anglo-American Cataloguing Rules (AACR), a large majority of libraries used the Dewey Decimal Classification (DDC), dictionary catalogues were used by 14 libraries, using Library of Congress List of Subject Headings or Sears' List of Subject Headings, most libraries indicated that British Library and LCMARC records would need modification (e.g. adaptation of classification numbers and subject headings and simplification of descriptive cataloguing), 24 libraries stated that a centralized cataloguing service would be of value and expressed a preference for a card service, very few computerized library services existed in South Africa but twelve libraries indicated that they were considering it, few libraries could provide information on the cost of processing monographs and those who could did not use a standardized method of costing, monographs ordered from abroad took four to six months to arrive in South Africa, and the time lapse between acquisition of items and appearance of records in the catalogue took from one to six months (Kingwill 1979:6).

Six libraries participated in a detailed study of monograph acquisitions in their libraries, to obtain information on all stages of processing to determine the proportion of monographs likely to be covered by planned and existing MARC services, which MARC service should be subscribed to by a MARC centre and to what extent back issues of MARC tapes would be required. Findings included the following:

- $84.6 \%$ of the monographs acquired were in English

- 75.8\% were published either in the United States or United Kingdom

- MARC coverage of current acquisitions were $43.3 \%$

- $71 \%$ of the items were published in the previous three to five years

- ISBNs were found for only $53.3 \%$ of the acquisitions, although the percentage was higher for publications published since 1970 (few were however available at the moment of ordering, indicating that another form of identifying items would have to be found, particularly for computerized acquisition systems).

It could therefore be concluded that data on UKMARC and LCMARC tapes were sufficient to make an experiment valid, MARC records would be acceptable to South African libraries and that there were enough potential users for MARC tapes, judging by the number of libraries indicating that they were planning to computerize (Kingwill 1979:7).

The Working Group then recommended that an experimental centralized MARC service be established for two years to determine how the MARC system worked in practice, estimate benefits to participating libraries, provide practical experience in the use of MARC records and to determine if the establishment of a centralized MARC service would be feasible. These recommendations were approved by the Committee on Bibliographic Services and subsequently by the NLAC on 15 August 1972 (Kingwill 1979:7).

\section{Experimental MARC Service}

It was originally recommended that the experimental MARC Service should be carried out by the State Library and the CSIR, but the State Library was unable to participate due to staff shortages and the CSIR carried out the project under the guidance of the MARC Working Group (MWG), a committee appointed by NLAC in 1973 to replace the previous working group. Funds requested from the Department of National 
Education in 1972 only became available in 1974 for the initial period April 1974 to March 1976. Subscriptions to the UKMARC and LCMARC tapes were placed and the British Library programmes for record selection services and an SDI (Selective Dissemination of Information) were bought, studied and adapted. Services were planned during this initial preparatory period, and to allow for input from all interested parties, the initial project was extended to March 1977. A trial MARC record selection and SDI services were introduced in January 1975 using the LCMARC and UKMARC tapes. The LCMARC tapes were converted to UKMARC format by the British Library and all UK records eliminated from them (Kingwill 1979:7).

During this initial trial period six libraries experimented with the service. They were asked to provide detailed information regarding the acceptability of the cataloguing information on the tapes. This information aided in the design of catalogue card format with the essential bibliographic elements printed on a main card and the less important elements on a second card. This was later used in the development of a mini-SAMARC format. Analysis of bibliographic elements indicated that important bibliographic elements were not necessarily used in the same form as that given in the MARC records, which was also confirmed by the findings of the experimental record selection service.

The MARC experimental services were made available to all libraries in mid-1975. The services were provided free of charge on condition that all libraries using the MARC service provide feedback and statistics needed for evaluation. The Record Selection Service initially provided for the selection of specific records by means of ISBN, LC card number, or author/title. However it was found that ISBN requests were the most successful during 1975, and thereafter provision was made only for ISBN requests. Selected records were distributed in printed form, either on a catalogue card or on paper, or on magnetic tape. Requests were matched on a weekly basis against the updated MARC database over a maximum period of six weeks, after which they were deleted if no match had been found (Kingwill 1979:7).

A questionnaire to participating libraries indicated that some additions or alterations to the MARC records were necessary, due to specific requirements of some libraries. Sixteen from 21 libraries indicated that they would consider continuing using the MARC service. By March 1977, 39 libraries were using the SDI Services, primarily for book selection and ordering (Kingwill 1979:9).

During this period considerable expertise and understanding regarding MARC records was gained. Because comparable costs were unavailable, it was however impossible to evaluate the cost or benefit of this service. Some changes were recommended, such as: improving the retrieval procedures, improving the search procedures of the SDI programmes, making provision for alteration of the MARC records if required, investigating means of improving the currency of MARC record and determining whether adequate coverage for South African libraries was provided on the tapes (Kingwill 1979:9).

\section{RSA MARC service}

In June 1976 NLAC requested the CSIR to take over the responsibility for the continuation of the experimental service. The CSIR agreed and the RSA MARC Service was established in June 1977 on a subscription basis. Due to a shortage of staff, the CSIR was unable to publicize or improve the service. The response was disappointing. In May 1977 only eight libraries were using the SDI Service and five the Record Selection Service (Kingwill 1979:9).

\section{Investigation into a co-operative cataloguing network 1977}

During the feasibility study the MARC Working Group and the NLAC came to the conclusion that the MARC experimental services formed only part of a broader project namely a co-operative cataloguing network (Roos 1994:27). The MARC Working Group was requested to investigate and report on the acceptability of MARC records, compatibility of software of existing systems with MARC records and costs involved in the use of MARC records, before submitting a framework for such a network (Kingwill 1979:10).

A survey was done sending questionnaires to 153 libraries of which 80 were returned. A number of recommendations were made regarding a network. The co-operative cataloguing network project was launched in 1979.

\section{Development of the SAMARC format}

In the seventies a number of South African libraries were computerizing their procedures. The MARC project provided valuable experience in the handling of machine-readable records in the experimental catalogue record selection and SDI services conducted during the period January 1975 to June 1977. These records were distributed to libraries participating in the experiment and were utilized in various ways, thus familiarizing librarians with MARC records and making them aware of the potential value of the exchange of machine-readable bibliographic records. An important lesson learnt during these experiments was that, if libraries are to achieve the maximum benefit from co-operation and computerized services, standardization of cataloguing data is a prerequisite, avoiding waste of time, manpower and money through unnecessary duplication and imprecise and difficult communication.

Some progress had been made internationally in the standardization of the content of the bibliographic description with the development by IFLA of the ISBDs (International Standard Bibliographic Description). The publication of a second and unified edition of the Anglo-American Cataloguing Rules (AACR) in 1978 and updated in 1988, which included the ISBDs, also promoted standardization. AACR2 is used by many countries and also by virtually all South African libraries. 
It is however just as important that the format in which the content of bibliographic records is coded for use in computerized systems and for the exchange of records, is standardized and consequently compatible with other formats. Because no South African standard for the exchange of machine-readable records was available, libraries planning to computerize their activities were forced to choose one of the available formats or to develop an entirely new format. This could lead to such diversification of formats as to make the effective exchange of machine-readable records very difficult or, in some cases, virtually impossible, hampering co-operation efforts severely. It became evident that it would be greatly beneficial if a South African exchange format were available (Roos 1994: 27). The NLAC MARC Working Group was aware of the advantages of a national format for South Africa and investigations were carried out on their behalf since January 1976 , paving the way for the development of SAMARC.

The existence of a national format for the exchange of bibliographic information would however not imply its full or even partial use by single libraries. As many internal processing formats could exist as there are libraries, but their degree of compatibility with the national exchange format would determine the degree of benefit to be gained by these organizations from computerization and co-operation in national bibliographical services.

In a progress report on a national exchange format, submitted to the MARC Working Group by Van Niekerk in May 1978 , it is stated that research had been done regarding the identification of all possible applications for such a standard, the establishment of general format requirements, the establishment of format requirements specifically applicable to South Africa, the establishment of format requirements for individual-use situations, a study and comparison of existing national formats in the Anglo-American library community, a study of provision for bilingualism in existing formats, a study of UNIMARC and comparison with other formats, and ascertaining if these formats met South African requirements. If no existing format met South African requirements, a South African format should be developed.

UNIMARC was studied extensively and found to be the best possible basis for a national format. Testing in an experimental situation was recommended. Lectures were given in various places, enquiries regarding the format were answered and questionnaires were sent out by the MARC Working Group in 1977 and by the State Library in 1978. A course was also given in 1978 and would be repeated if interest was shown. The experimental application of UNIMARC was done on three levels: the complete format by SANB staff; the standard format according to AACR2 by CSIR staff; and minimum description by libraries contributing to the joint catalogue.

Problems encountered were mostly attributed to incorrect interpretation of codes, lack of knowledge of ISBD principles and some specific local requirements. The two unsolved problems were multilingual cataloguing and dealing with surnames consisting of separate elements. A South African national format would have to address these problems (Van Niekerk 1978 Vorderingsverslag: 1-5).

In July 1978 Van Niekerk submitted the SAMARC development report to the MARC Working Group outlining the objectives, uses, general and specific requirements of SAMARC.

The objectives are to develop a national standard for the exchange of machine-readable bibliographic descriptions for use in South Africa by investigating all possible situations in which such a standard would be useful, investigating general format requirements and requirements resulting from the South African situation, investigating special format requirements in individual situations, comparison of existing national formats, comparison of existing national formats catering for requirements of bilingualism, study of the UNIMARC format and comparison with other formats and investigating the ability of these formats to accommodate South African requirements. If no existing format proved to be satisfactory, a format for South African requirements was to be developed. This format would then be tested through the experimental coding of bibliographic records and the acceptability of the proposed format through communication with the South African library community.

Uses of the format were seen to be the following: a national standard for the exchange of machine-readable bibliographic records in South Africa would act as an interface between all libraries and bibliographic agencies and between the library community and the booktrade, and could be implemented as a means to centrally produce authoritative, standardized, machine-readable bibliographic records for new library materials published in South Africa, to distribute these records to South African libraries as required, to convert records to the UNIMARC format for international distribution, convert records received form other countries which are coded in UNIMARC or in one of the various national formats to SAMARC, distribute these foreign records to South African libraries as required, maintain a MARC data base containing records generated in South Africa as well as foreign records converted from other formats, report to national or regional union catalogues, exchange bibliographic records for purposes of library co-operation, such as an interlibrary loan system, exchange machine-readable records between libraries and the booktrade and provide for publishers to report publications to the copyright libraries.

Format requirements were stated to be the following: a SAMARC format should be compatible with the international exchange format (UNIMARC), and local library formats, have a detailed tagging system capable of identifying individual data elements for retrieval or manipulation, be able to carry authority file information or provide links to separate authority files, be suitable for all bibliographic and physical types of material, be suitable for the production and distribution of information in different physical forms, for example cards, magnetic tape, printed bibliographies, microfiche, et cetera, allow for minimum and maximum descriptions, be suitable for macro- and micro-analytical use, be 
sufficiently flexible to allow for national and international developments in record content, include as retrieval aids coded information not normally included in a bibliographic description or not easily accessible in machine searching, for example intellectual level, chronological coverage, bibliographic form of contents, have capabilities to link related records in three ways: vertically, horizontally and chronologically, include filing information, provide for the inclusion of holdings statements for reporting to union catalogues, provide for unique identification of bibliographic records, provide for the value coding of records on completeness of description, level of authentication and form of cataloguing, provide for status coding of records, such as new, corrected and deleted, reserve an area for individual libraries to include private information not intended for exchange and also provide for existing and future national and international standards to be used.

Specific South African requirements were stated to be the following: because of the multilingual community in South Africa and the existence of two official languages, most official publications and many other works are published in two and sometimes several languages. If not all bibliographies, at least the national ones should be provided with bilingual indexes. The national format should therefore provide the means to identify the language of the work, identify the language in which the work is catalogued, identify and relate the same work in different languages or editions, provide links to an authority file of variant personal and corporate author names with equivalences, use bilingual systems of subject descriptors, use codes which are easily translated into a required language such as equivalences for languages, geographic names and relator terms) and also provide for possible bilingual, multilingual, or preferred language cataloguing of multilingual or other works (Van Niekerk 1978 Development report). These specific South African requirements could not be satisfied in a logical way using either USMARC or UKMARC, but the UNIMARC structure with additions made it possible.

\section{Publication of the SAMARC format}

\section{SAMARC: Draft format 1977}

Because very few South African librarians had a thorough knowledge and experience of computerization, it was felt that ordinary circulation of the proposals asking for comments and criticism would not have great value. It was then decided to arrange courses in all the main cities of South Africa on ISBD and SAMARC to explain the format before asking South African librarians to comment on the acceptability of the format. The participants in these courses served as contacts when the format was circulated to all libraries who had indicated their interest or participation in the MARC Working Group questionnaire of 1977. During July/August 1977100 copies of the draft SAMARC were circulated for comment and voting. After acceptance of the proposals by the library community, the SAMARC format was accepted by the Committee for a Computerised Cataloguing Network and the
National Library Advisory Council in March 1980 (Van Niekerk 1983:89).

In March 1980 the first edition of SAMARC was published by the NLAC. The format complied with ISO 2709, UNIMARC, AACR2 and ISBD, as well as the requirements for cataloguing in more than one language, in accordance with the objectives set by Van Niekerk in her development report of 1978 (Roos 1994:27).

\section{SAMARC: first corrected edition 1982}

The preface to the first edition (corrected) of the SAMARC format stated that: the establishment of a national format for the exchange of machine-readable bibliographic information was seen as a prerequisite to co-ordinated resource sharing by computerized library and information services within the Republic of South Africa. The SAMARC format was consequently created. It is our recommendations that libraries and information services planning for computerization should use the SAMARC to facilitate co-operative data exchange.

In the introductory notes the scope, purpose and use of the format is described as follows:

'The South African MARC format, referred to hereafter as SAMARC, is a communications format based on UNIMARC, and specifies the tags, indicators and subfield codes to produce bibliographic records in machine-readable form for all bibliographic and physical forms of library materials. The primary purpose of SAMARC is to facilitate the national exchange of bibliographic data in machinereadable form between centres and to provide an easy conversion to an international format for the purpose of making South African national bibliographic records available to other countries. It is anticipated that each South African library will be responsible for the translation of bibliographic records from its own processing format into SAMARC for transmission to other libraries and will receive machine-readable records in the SAMARC format from other libraries and translate them into its own processing format. SAMARC is intended to provide the information required for a range of bibliographic activities. It therefore includes a comprehensive set of content designators of which some may be essential to one or another of these activities, but not to all' (SAMARC 1982: v).

The development and publication of SAMARC was a remarkable achievement, particularly as virtually all the work had been done by an individual, namely Ilse van Niekerk. The development of a national MARC format for South Africa had wider applications, making it possible for South Africa's neighbouring countries to participate in co-operation and resource sharing in Southern Africa. The use of SAMARC as an input format by bibliographical centres in the region, as well as its implementation as the input and communications format in the South African Bibliographical and Information Network (SABINET), were important steps towards the 
realization of meaningful co-operation in the field of bibliographic control, nationally and internationally (Roos 1994: 27).

SAMARC was published in a loose-leaf duplicated format in 1982 and could be acquired from the Department of National Education. It has since been used extensively in the South African library community. The format was also implemented as the base record format for various commercial library systems, or systems developed as in-house systems within their own organizations (Van Niekerk 1995:7).

\section{SAMARC: updating and maintenance since 1981}

When SABINET was established in 1983, Van Niekerk joined their staff after being a member of the investigation team. SAMARC remained the responsibility of Van Niekerk after an agreement that gave SABINET the technical responsibility for the format while the State Library and the CBC were to promote bibliographic standardization. At the beginning of the development of SAMARC, the CSIR was at its heyday of government funding and thus absorbed the cost of the investigations and development of the format. When Van Niekerk left to join SABINET, no one conversant with SAMARC remained at the CSIR to continue her work. It could also not really be expected of the CSIR to continue the funding of this project. In other countries the national cataloguing agency usually has responsibility for format development and bibliographic standardization, but the State Library could not assume this technical format responsibility because of a lack of expertise, staff and funds. The NLAC was also not replaced by another national body responsible for development of library and information services in South Africa. It was also not part of the brief of the then Division of Government Libraries to promote standards, except in the government service. Copies of SAMARC were however sold by the Department of National Education until they ran out of stock. SAILIS had a number of professional committees, some debating on standards, but consisting of part-time members, not having time to devote to the actual development and maintenance of any standard.

Responsibility for the technical machine format was transferred to SABINET, because of their responsibility, nationally and internationally, for the exchange of bibliographic data. Formulation of standards would in principle become the responsibility of SAILIS, but the State Library would be responsible for the application and promotion of standards, by applying them in the national bibliography and doing quality control regarding the co-operative cataloguing database of SABINET (Van Niekerk 1995:4). Although Van Niekerk attempted to keep up-to-date with MARC developments abroad and to continuously update SAMARC, it was in her own time with limited secretarial support. No amendments or revisions were published or made available to users of the format. Although maintenance of a format is an enormous task, no attention was given to SAMARC in this respect during the late eighties and early nineties. After Van Niekerk left SABINET, the responsibility for the format was transferred to the SAILIS Committee for Bibliographic Control (CBC). Proposals for additions and changes to the format were circulated during 1990/91 by the Network Standards Committee of SABINET. Proposals for change could be made to the $\mathrm{CBC}$. The $\mathrm{CBC}$ consists of a small number of members, with a member each representing bibliographic standards, indexing, bibliographic awards and the status of the national bibliographic tools. It has no real expertise as a committee, no real infrastructure and no funds (Van der Merwe 1996:12).

In the early nineties the South African library community was getting anxious about the absence of an updated national format and was also asking for an authorities format to be developed. Most university and technikon library schools were providing training in SAMARC, but only a few taught students how to complete coded fields. Some other training courses were offered by SAILIS interest groups and during summer or winter schools at universities and technikons. Very few libraries contributing to SACat completed coded fields, limiting the possibilities that SAMARC has to offer for making subsets of specific kinds of material, such as government publications, conference papers, biographies and others available to users. It was generally felt that a revision and updating of SAMARC was overdue, but no institution was prepared to take the initiative. Because she had the expertise and felt a responsibility for SAMARC, Ilse van Niekerk offered her services to the $\mathrm{CBC}$ to act as editor for a revised and updated SAMARC. The CBC member representing the State Library offered the services of publishing and marketing SAMARC. An agreement was reached between the State Library, the CBC and Ilse van Niekerk to commence work as soon as possible.

Because such a long time had elapsed since any real work was last done on the format, it was a huge task, and because it was done on a part-time basis, it took longer than anticipated. Questionnaires, requesting comments, was sent out to a large number of libraries, but only about 60 actively participated in commenting on proposals. A special subcommittee of the $\mathrm{CBC}$ was formed, with Helena Coetzee as chairman of the CBC Subcommittee on Bibliographic Standards as convenor, and Lettie Erasmus (Unisa), Barbara Kellerman (State Library) and Francien Maritz (MEDUNSA) as members. Ilse van Niekerk was appointed as editor/compiler. The task of this committee was to adapt the references to AACR2 rules (1978 edition) numbers in the 1982 SAMARC format to those in the AACR2 1988 revision. SAMARC was also meticulously compared to the latest edition of the UNIMARC manual, following the general outline, much improving the clarity and ease of use of the format. Examples were also added with help of Unisa library, providing guidelines to cataloguers on the application of the format. Van Niekerk worked through the comments received from the library community and as many as possible were accommodated in the new edition. It was planned to send out further amendments regularly. For this purpose it was decided to publish SAMARC in a loose-leaf form, making it possible to remove and insert new pages in the future. A glossary was compiled 
by Marlene Burger from Unisa, which would be distributed later. The compilation of an index, aimed at facilitating use of the manual, was also envisaged. The committee also undertook the proofreading of the format after receipt from the State Library.

The revised edition was made available in draft form under the title SAMARC manual at a training workshop held at the University of Pretoria in June 1994. Comments received during this well-attended workshop were also incorporated in the revision. Eventually the SAMARC manual was published after many delays, in the second half of 1995 and ceremoniously handed to Albert Viljoen, then President of SAILIS, at the annual conference of SAILIS in Cape Town in September 1995 by a member of the State Library. There was also a display of the Manual at the conference, where orders could be placed for the new edition.

The editor was not paid by the State Library for her services, but would only received a small percentage of the price of copies sold. The $\mathrm{CBC}$ regarded this as unfair treatment because many hours of work had been devoted to the updating of the manual, for which no payment had been received. A letter was written by the chairman of the CBC Subcommittee for Bibliographic Standards to the SAILIS Council, who then decided to pay the editor a modest honorarium.

In the preface to the SAMARC manual, Dirk Fokker, then chairman of the CBC gives the reasons for the urgency in updating the format. Developments which have taken place in the area of machine-readable bibliographic information within South Africa and overseas are the following:

- SABINET became a reality in 1983 using the WLN system with the USMARC format as basis. A SABIMARC screen format was soon developed to provide a familiar SAMARC-like screen and input format. In 1992 SABINET implemented a SAMARC-based system.

- Many South African libraries have computerized their inhouse procedures since that time and the majority have adopted SAMARC-based systems or the SAMARC format for the exchange of bibliographic records. Some overseas library system packages were also converted to a SAMARC format base.

- South African libraries therefore have a very large investment in the SAMARC record format for computerized bibliographic information. During the course of these applications certain problems and shortcomings in handling data elements from records received in other national and international formats were identified by individual libraries and the Network Standards Committee of SABINET.

- Proposals for additions and changes to the SAMARC format were circulated during $1990 / 91$ by the Network Standards Committee. Some of these proposals were applied selectively by SABINET and a number of libraries.

- UNIMARC was finalized in 1983 and updated in 1987. An increasing number of bibliographic agencies are providing for the exchange of their bibliographic records in the UNIMARC format. In some cases national formats have been changed to comply with UNIMARC coding. To facilitate the transfer of bibliographic records received in foreign national formats to SAMARC-based systems, formats should be highly compatible to prevent the loss of data definition during the data conversion process. Identical coding ensures transfer without complicated translation processing, while compatibility together with a high level of bibliographic data identification ensures an easy and logical conversion process.

- Compatibility with USMARC has become more important, because this is the main source of foreign records utilized by the South African library community the Anglo-American Cataloguing Rules, 2nd ed (AACR2), accepted as the de facto South African standard for bibliographic descriptions, was again revised in 1988.

- Relevant ISO standards, especially those used as code lists, saw further extensions. In addition, various new standards have been developed, for example for unique identification numbers in standardized form.

- All copies of the first edition of the SAMARC format have long been sold out (SAMARC manual 1995:vi).

In May 1995, Van Niekerk submitted a proposal to the CBS for the continued maintenance of the format. In this report she recommended that a permanent SAMARC office be established at a national organization, willing to undertake maintenance of the format and support it financially. At least one staff member was required to man this office. The SAMARC Workgroup could act as management committee. The wider library community should be involved by correspondence to give information and comments on changes. Expert representatives from each region should meet at least once or twice a year to finalize changes and updating. Vendors of library systems should also be involved to ensure their co-operation. A detailed motivation is given for this recommendation (Van Niekerk 1995:1-4).

A letter was consequently written by the chairman of the CBC Subcommittee on Bibliographic Standards to the Council of SAILIS on this matter, but no reply was received. With the change to USMARC, it is also felt that a permanent MARC office, situated at the State Library, was essential, because SAMARC will still be used for a number of years and USMARC will also have to provide for unique South African requirements. This office should also co-ordinate training - a matter which has been vastly neglected in the past, and which is essential for consistent application of a format.

\section{Conclusion}

Even though much enthusiasm existed initially for the updated format, matters changed drastically during 1996. Unisa started active lobbying for a changeover to USMARC. Brochures were distributed with the title: SAMARC: Quo vadis? A detailed position paper on SAMARC was compiled and distributed, clearly stating that Unisa regarded USMARC as the better option. When Unisa and GAELIC decided to 
acquire INNOPAC, a USMARC-based system, the writing was on the wall. The Interim Committee for Bibliographic Organization (ICBO), which has taken over the responsibilities of the $\mathrm{CBC}$, however felt that a one-sided decision by some libraries and maybe SABINET, to no longer support SAMARC, was not acceptable and that the whole South African library community should be consulted before it was finally decided to go for USMARC. For this purpose a survey was done by Retha Snyman at the beginning of 1997, and its results were discussed at a seminar, held at the University of Pretoria at the end of April 1997. GAELIC however preempted decisions to be taken at the seminar, by deciding during the week prior to the seminar to adopt USMARC. The majority of people attending the seminar, decided that a changeover to USMARC was the best option. UNIMARC received some support and few wanted to retain SAMARC.

\section{Acknowledgement}

The author wishes to thank Ilse van Niekerk for reading this article before publication to ensure that all the facts are correct.

\section{References}

Attig, J.C. 1989. Descriptive cataloguing rules and machine readable record structures, in Conceptual foundations of descriptive cataloging. San Diego: Academic Press.

Chan, L.M. 1985. Cataloguing and classification: an introduction. New York: McGraw-Hill.

Chan, L.M. 1989. Conceptual foundations of descriptive cataloguing. San Diego: Academic Press.

Gorman, M. 1990. Descriptive cataloging: its past, present and future, in Technical Services today and tomorrow. Englewood Cliffs, Colo: Libraries Unlimited.

Hagler, R. 1991. The bibliographic record and information technology. 2nd ed. Chicago: ALA.

Hunter, E.J. \& Blakewell, K.G.B. 1991. Cataloguing. 3rd ed. London: Library Association Publishing.

Hunter, E.J. 1985. Computerized cataloguing. London: Bingley.
Kingwill, H. 1979. A history of the MARC project in South Africa. South African libraries, 47(1):5-12.

Library technical services. 1984. Orlando: American Press.

National Library Advisory Council Committee foraComputerized Library Network Working Group for Bibliographic Standards. 1982. SAMARC: South African National Format for the Exchange of Machine-readable Bibliographic descriptions, 1st ed: (corr). Pretoria: NLAC.

Piggott, M. A topography of cataloguing. London: Library Association.

Review of metadata: a survey of current resource description formats. 1997. [Online]. Wysiwyg//11/http://www.ukoln.ac.uk.

Roos, A. 1994. The South African MARC format (SAMARC). International cataloguing and bibliographic control 23(2):2628.

Rowley, J. 1992. Organizing knowledge. 2nd. ed. Aldershot, Hants.: Ashgate.

SAMARC manual. 1995. Pretoria: State Library.

Snyman, M.M.M. 1997. Future machine-readable cataloguing format for South African libraries. Pretoria: Department of Arts, Culture, Science and Technology.

Taylor, A.G. 1992. Introduction to cataloguing and classification, by Bodhan S. Wynar. 8th ed. Englewood, Colo.: Libraries Unlimited.

Technical services today and tomorrow, compiled by Michael Gorman. 1990. Englewood, Colo.: Libraries Unlimited.

Van Niekerk, I. 1978. SAMARC: development report to the MARC Working Group D. (Unpublished).

Van Niekerk, I. 1978. SAMARC: Vorderingsverslag aan die MARCwerkgroep, Mei 1978. (Unpublished).

Van Niekerk, I. 1983. SAMARC: its background, development and application. (Unpublished).

Van Niekerk, I. 1995. SAMARC: the requirement for a national exchange format for machine-readable bibliographic descriptions. (Unpublished).

Van Niekerk,I. 1995. Voortgesette instandhouding van die SAMARC-formaat: verslag met aanbevelings. (Unpublished).

Van Niekerk, I. 1995. Voortgesette instandhouding van die SAMARC-formaat. (Unpublished).

Van der Merwe, H.C.J. 1996. SAMARC vs USMARC and UNIMARC: a position paper. (Unpublished). 